\title{
The Effects of Salinity and Light to the Seed Germination Ofmung Bean (Vigna Radiata L..)
}

\author{
Muhammad Jamhari* \\ Postgraduate Program of Biology Education, Universitas Negeri Medan, Medan, Indonesia, Jl. Willem \\ Iskandar Psr V Medan Estate-Indonesia (20221)
}

*Corresponding Author: Muhammad Jamhari, Postgraduate Program of Biology Education, Universitas Negeri Medan, Medan, Indonesia, Jl. Willem Iskandar Psr V Medan Estate-Indonesia (20221)

\begin{abstract}
The objective of this study was to find out the effects of salinityand light to the seed germination of mung bean (Vigna radiataL.) which had been conditioned for three treatments, namely the first sample of mung bean was placed on the medium with any direct sunlight, the second one was placed on the medium without any sunlight (in the dark) and the third one was placed on the medium with less sunlight. This study was conducted in the Experimental Greenhouse ofFaculty of Mathematics and Natural Sciences, The State University ofMedanon October 2015 for five days (approximately 120 hours). The researcher selected the mung beanfor this study due to its short life cycle so thatit was more easily to be observed and experimented as well. The method of data collectionused the documentation and measurement, and also the description and quantitative technique was applied in this experiment. The results showed that salinity and light significantlyinfluenced the seed germination of mung bean. The seeds of mung beanwhich were treated to $0 \%$ of salt on themedium with any source of sunlight had a better growth of germination rather than those seeds with $0 \%$ of salt on the medium without any sunlight as well as less sunlight. The seeds of mung beanwith $2.5 \%$ of salt in the dark and light condition still had a low germination,meanwhile those seeds were placed on the medium with less light had no germination occurred. The seeds of mung bean with the concentration of 5\%, $7.5 \%$, and $10 \%$ consecutively upon three treatments showed no germination processes until the end of the observation. This has been shown that salinity and light had the very significant effects to the germination process of mung bean.
\end{abstract}

Keywords: Salinity, Light, Germination, Mung Bean

\section{INTRODUCTION}

Germination is the growth of a plant contained within a seed; it results in the formation of the seedling, it is also the process of reactivation of metabolic machinery of the seed resulting into the emergence of radicle and plumule. The seed of a vascular plant is a small package produced in a fruit or cone after the union of male and female reproductive cells. All fully developed seeds contain an embryo and, in most plant species some store of food reserves, wrapped in a seed coat. Some plants produce varying numbers of seeds that lack embryos; these are called empty seeds. Dormant seeds are ripe seeds that do not germinate because they are subject to external environmental conditions that prevent the initiation of metabolic process and cell growth. Under proper conditions, the seed begins to germinate and the embryonic tissues resume growth, developing towards a seedling ${ }^{[1]}$.

Seed germination depends on both internal and external conditions. The most important external factor is light or darkness. Light or darkness can be an environmental trigger for germination and is a type of physiological dormancy. Most seeds are not affected by light or darkness, but many seeds, including species found in forest settings, will not germinate until an opening in the canopy allows sufficient light for growth of the seedling ${ }^{[2]}$.

High salinity is a common abiotic stress factor that seriously affects crop production like mung beanin some parts of the world, particularly in arid and semi-arid regions ${ }^{[3]}$. Germination is one of the most critical periods for a plant subjected to salinity. Salt stress has been shown to decrease the germination percentage and germination rate of some plants ${ }^{[4]}$. Soil salinity may influence the germination of seeds either by creating an osmotic potential external to the seed preventing water uptake, or the toxic effects of $\mathrm{Na}^{+}$and $\mathrm{Cl}^{-}$ions on germinating seed ${ }^{[5]}$. Salt and osmotic stresses are responsible for both inhibition or delayed seed germination and seedling establishment ${ }^{[6]}$. Seed germination, seedling 
emergence and early survival are particularly sensitive to substrate salinity ${ }^{[7]}$. Salt stress affects germination percentage, germination rate and seedling growth in different ways depending on plant species $^{[8]}$. Germination and seedling growth are reduced in saline soils with varying responses for species and cultivars ${ }^{[9]}$. Mung bean was determined to be moderately salt sensitive relative to other species $^{[10]}$. Against these stresses, plants adapt themselves by different mechanisms including change in morphological and developmental pattern as well as physiological and biochemical responses ${ }^{[11]}$.

\section{RESEARCH METHOD}

\subsection{Location, Time, and Sample of the Study}

This study was conducted in the Experimental Greenhouse of Faculty of Mathematic and Natural Sciences, The State University of Medan on October 2015 for five days (approximately 120 hours). The samples were mung beans(Vigna radiataL.), where the first sample was placed on the medium with any direct sunlight, the second one was placed on the medium without any sunlight (in the dark) and the third one was placed on the medium with less sunlight.

\subsection{Materials and Devices}

This experiment required 60 plastic scuttles, 1.000 gram of cotton, 3 nippers, 15 of $500 \mathrm{ml}$ measuring glass and 60 sheets of labelling paper. It also required 60 seeds of mung bean(Vigna radiataL.), 500 gram of salt $(\mathrm{NaCl})$ and $2.500 \mathrm{ml}$ of water

\subsection{Research Procedure}

First of all, the seeds of mung beanswere selected and gathered from the local market. The healthy seeds were subsequently sorted and soaked in the water for an hour. Cotton was placed over the scuttle as the medium of germination. We prepared 60 scuttles. Those seedswere then placed over the scuttle, and each of five mung beans' seeds were placed over the scuttle. For every treatment of this research was taken into four scuttles. Subseuently, each scuttle was sprinkled with a teaspoon of water and salt, and it was conducted for five days. This observation was employed everyday by measuring the length of plant. The design of this research procedure was presented in Table 1.

Table1. Research Procedure Design

\begin{tabular}{|l|l|l|l|}
\hline Salinity & Dark & Less Light & $\begin{array}{l}\text { Light } \\
\text { (Adequacy of Light) }\end{array}$ \\
\hline $0 \%$ & $* * * * *$ & $* * * * *$ & $* * * * *$ \\
\hline $2.5 \%$ & $* * * * *$ & $* * * * *$ & $* * * * *$ \\
\hline $5 \%$ & $* * * * *$ & $* * * * *$ & $* * * * *$ \\
\hline $7.5 \%$ & $* * * * *$ & $* * * * *$ & $* * * * *$ \\
\hline $10 \%$ & $* * * * *$ & $* * * * *$ & $* * * * *$ \\
\hline
\end{tabular}

Description : * = scuttle, each scuttle contains 5 (five) seeds of mung beans

\subsection{Data Collection Method}

The methods of data collection used the documentation and measurement.

\subsection{Data Analysis Technique}

The data analysis applied the description and quantitative technique.

\section{RESULTS AND DISCUSSION}

\subsection{Results}

\subsubsection{Seed Germination of Mung Bean with Direct Sunlight}

The result of observation for the seed germination process with the source of direct sunlight was presented in Table 2 and Fig. 1.

Table2. The Result of Observation for the Seed Germination Process with Direct Sunlight

\begin{tabular}{|l|l|l|l|l|l|}
\hline \multirow{2}{*}{$\begin{array}{l}\text { Treatment of Saline } \\
\text { Water (\%) }\end{array}$} & \multicolumn{5}{|l|}{ The Germination Process with Direct Sunlight (cm) } \\
\cline { 2 - 6 } & Day 1 & Day 2 & Day 3 & Day 4 & Day 5 \\
\hline $0 \%$ & 0.5 & 3.4 & 5.6 & 6.4 & 7.2 \\
\hline $2.5 \%$ & - & - & - & - & - \\
\hline $5 \%$ & - & - & - & - & - \\
\hline $7.5 \%$ & - & - & - & - & - \\
\hline $10 \%$ & - & - & - & - & - \\
\hline
\end{tabular}




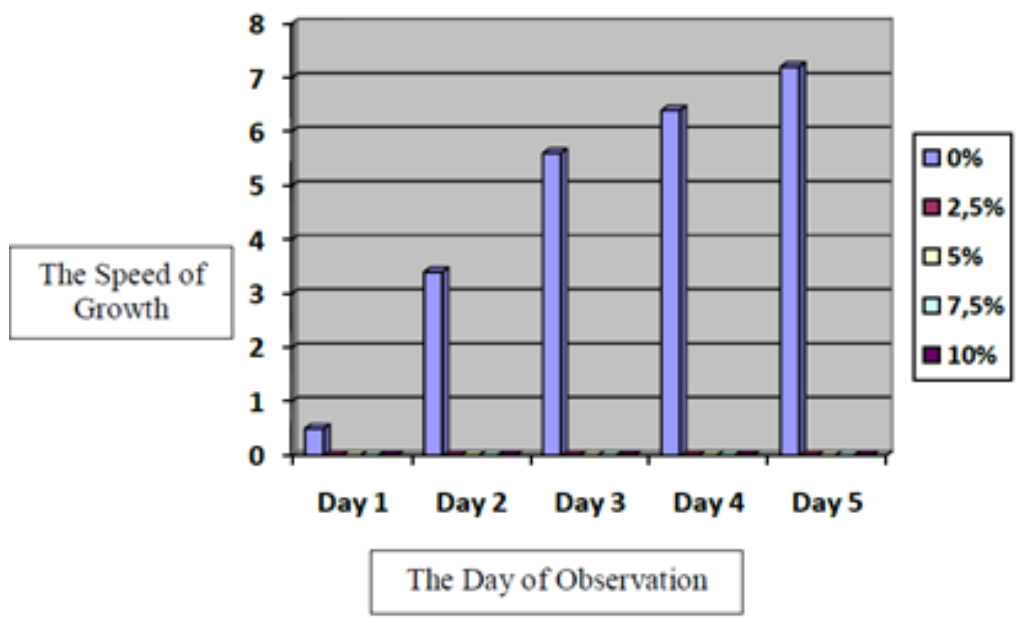

Fig.1. Seed Germination of Mung Bean with Direct Sunlight

The seeds were given to $0 \%$ of saline water started to the first day of observation had been visibly seen the signs of germination. On the first day of observation, the seed coat of mung bean ruptured, even the root has grown. The length addition of plant occurred from day to day until the end of the observation. On the third day, a little greenish leaf was apparently seen. The size of leaf grew well in width on the fifth day and the colour of leaf became so green. The observation of seeds which were given to $2,5 \%$ of saline water has not shown the signs of germination. The signs of germination appeared on the second day from the most of the mung beans' seeds. On the second day, the seed coat began to rupture but the root did not come up until the last day. The seeds which were given to $5 \%$ of saline water on the first day to the second day did not obviously appear the signs of germination. However, on the third day the seed coat ruptured but the root disappeared. Until the last day of the observation, there were no roots visibly seen and observed. Theseeds which were given to $10 \%$ of saline water started to the first day until the end of the observation showed no signs of germination process occurred.

\subsubsection{Seed Germination of Mung Bean with Less Sunlight}

The result of observation for the seed germination process with less sunlightwas presented in Table 3 and Fig. 2.

Table3.The Result of Observation for the Seed Germination Process with Less Sunlight

\begin{tabular}{|l|l|l|l|l|l|}
\hline \multirow{2}{*}{$\begin{array}{l}\text { Treatment of } \\
\text { Saline Water(\%) }\end{array}$} & \multicolumn{5}{|l|}{ The Germination Process with Less Sunlight (cm) } \\
\cline { 2 - 6 } & Day1 & Day2 & Day 3 & Day4 & Day5 \\
\hline $0 \%$ & 1.41 & 2.50 & 2.62 & 4.05 & 9.11 \\
\hline $2.5 \%$ & - & - & - & - & - \\
\hline $5 \%$ & - & - & - & - & - \\
\hline $7.5 \%$ & - & - & - & - & - \\
\hline $10 \%$ & - & - & - & - & - \\
\hline
\end{tabular}

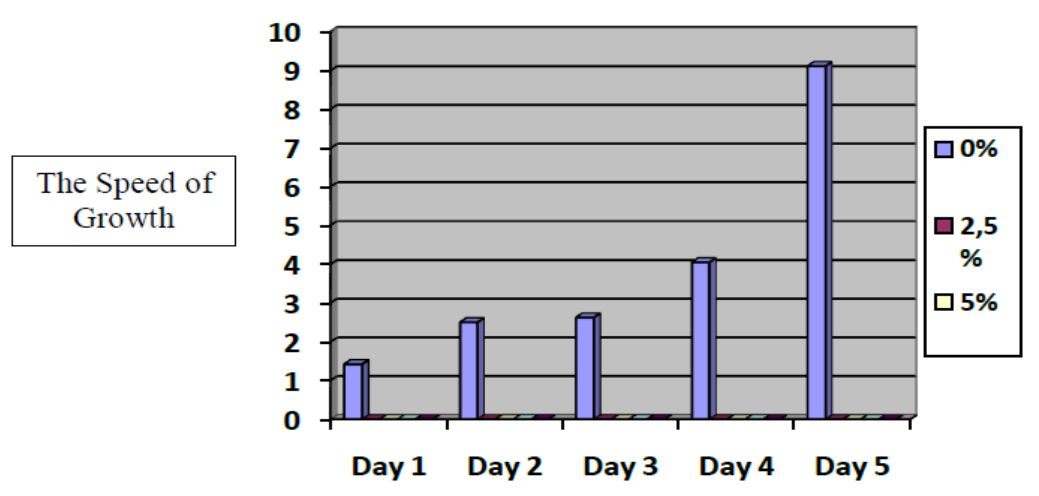

The Day of Observation

Fig. 2. Seed Germination of Mung Beanwith Less Sunlight 
The observation was conducted for five days. The observation on the first day has started after one day of treatment. Mung beans which were placed on the scuttle with $0 \%$ of saline water (control) had occurred the significant change that it started to grow on the first day to the last day of the observation, the leaf and stem of mung bean had also grown very well. The color of stem was quite greenish as well as the leaf in case of the circumstance of those samples. Those seeds were located in the open area, however the seeds obtained lighting from LED.

On the scuttle of seeds which were treated to the concentration of $2.5 \%, 5 \%, 7.5 \%$ and $10 \%$ of saline water had no any significant growth, the roots did not grow well until the end of the observation. There were only seeds became much bigger that indicates the saline water came into the seeds (imbibe) and most of the seed coats turned out into brown.

\subsubsection{Seed Germination of Mung Bean without Sunlight (In the Dark)}

The result of observation for the seed germination process without the source of sunlightwas presented in Table 4 and Fig. 3.

Table4. The Result of Observation for the Seed Germination Process without Sunlight (In the Dark)

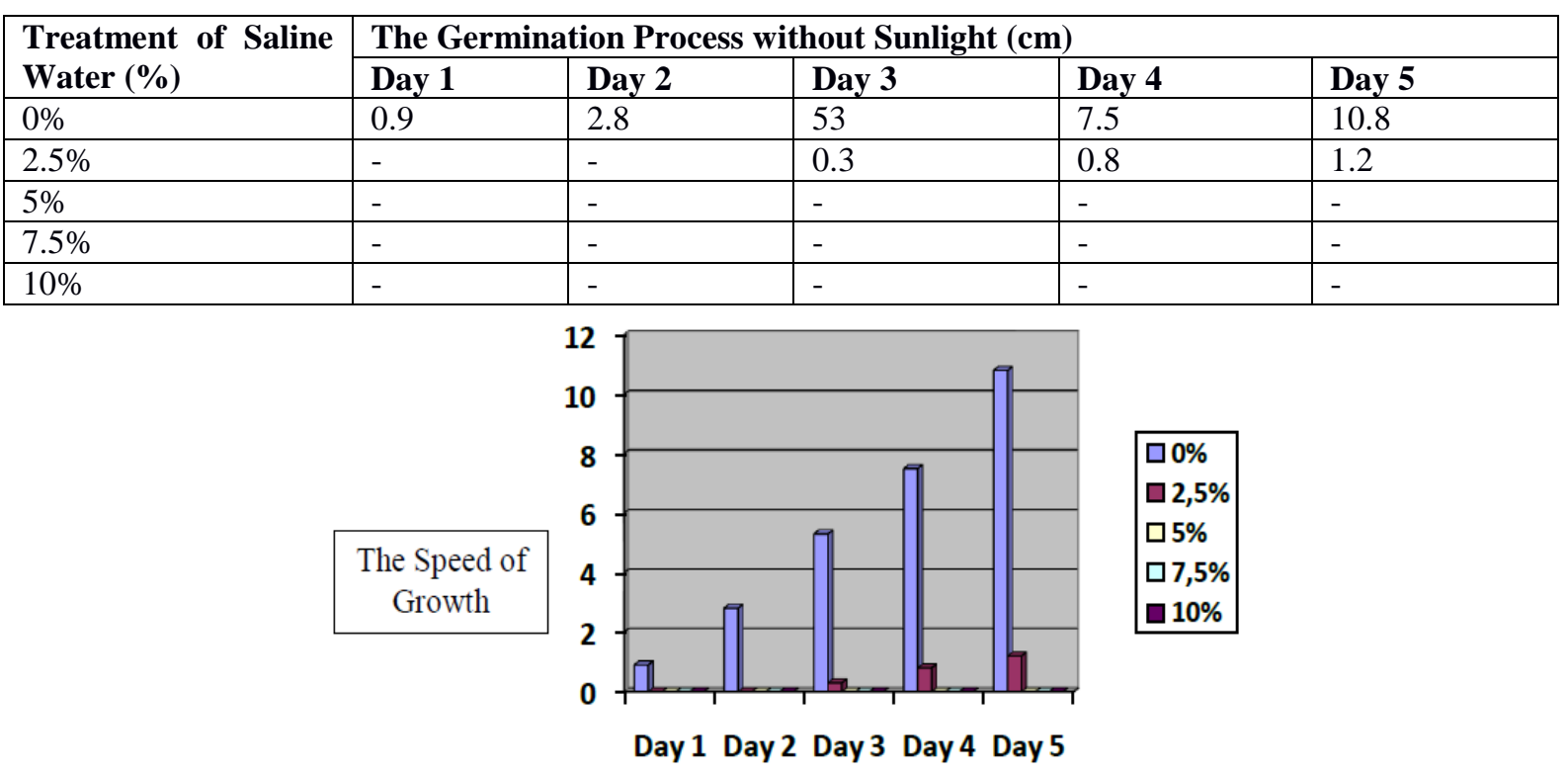

The Day of Observation

Fig. 3. Seed Germination of Mung Bean without Sunlight (In the Dark)

The seeds which were given to $0 \%$ of saline water started from the first day of observation, it had been obviously seen the signs of germination. On the first day of observation the seed coat had ruptured, even some rootshad grown well. The length addition of plant had occurred from day to day until the end of observation. Eventhough there were several mung beans' seeds inhibited of their growth. This was assumed due to internal factor of those seeds.

The seeds which were treated to $2.5 \%$ of saline water on the first day has not shown the signs of germination. The signs of germination appeared on the second day to the mostly seeds of mung beans. On the second day, the seed coat had ruptured as well as the root grown quite well. Eventhough most of the seeds did not germinate until the end of the observation. Its growth was too low and totally different than the mung beans' seeds which were given to only $0 \%$ of saline water.

The seeds which were treated to $5 \%$ of saline water on the first day to the second day had not been seen visibly the signs of germination. However, on the third day they had been visualized the rupture of the seed coat yet the root disappeared. Until the last day of any observation there were no roots had shown. On the last day of observation the seeds were infected by fungus so that it was rotten.

The seeds which were treated to $10 \%$ of saline water started from the first day until the end of the day had not been seen any signs of germination process. On the third day of observation, it was seen obviously the fungus, more and fungi contaminated the samples and lead to the decay of seeds. 


\section{DISCUSSION}

The observation was employed to mung beans' seeds for five days over three different treatment of those samples. Those conditions were placed in the dark place (without any sunlight), inside the room (less sunlight), and in the light place (with any direct sunlight).

The main effect of salinity or salt tolerance is the decrease of growth and crop production that cause the failure in crops. In the saline condition, growth as well as development of plants is inhibited because of the excess accumulation of $\mathrm{Na}^{+}$and $\mathrm{Cl}^{-}$ions in the cytoplasm, that cause the metabolic changes in the cell. The enzymatic activity is inhibited due to salt stress. Those conditions have also caused the partial dehydration of the cell and the loss of cell turgidity because of the decrease of water

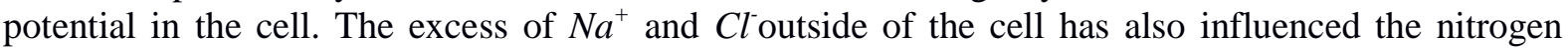
assimilation that is an important ion for the growth in plants ${ }^{[12]}$.

According to Simbolon (2013) the accumulation of salt inhibits the imbibition process due to the osmotic effects avoided the seed does imbibe and absorb the water from soil so that it is difficult to break the dormancy period and seed is also hardly to germinate. This is in accordance with the literature by Slinger and Tenison (2005) in Simbolon (2013) stated the salinity in certain quantity will have a big impact for the growth in plants. Salinity can also influence the growth in plants in three different ways: salt stress can force the osmotic effect off to avoid plants in water uptake from soil, certain ions can cause the toxicity in plants, for instance the concentration of higher $\mathrm{Cl}^{-}$in irrigation water can cause the leaf surface will be burned, particularly in application of water to leaf, and the effect of certain soil that influence the growth in plants ${ }^{[13]}$.

Salt stress declined the germination and also delayed the emergence of seeds in Vigna radiata $(\mathrm{L})$. It is also assumed that in addition to toxic effects of certain ions, higher concentration of salt reduces the water potential in the medium which hinders water absorption by germinating seeds and thus reduces germination $^{[14]}$. It appears that a decrease in germination is related to salinity induced disturbance of metabolic process leading to increase in phenolic compounds ${ }^{[15]}$. It is assumed that germination rate and the final seed germination decrease with the decrease of the water movement into the seeds during imbibitions ${ }^{[16]}$. Salinity stress can affect seed germination through osmotic effects ${ }^{[17]}$. Salt induced inhibition of seed germination could be attributed to osmotic stress or to specific ion toxicity ${ }^{[18]}$. Germination percentage also significantly decreased as the level of salinity of the medium increased ${ }^{[19,20]}$. These results are similar in line with Jeannette $e{ }^{a} l^{[21]}$. They found that the mean time to germination of almost all Vigna species increased with the addition of $\mathrm{NaCl}$ and this increase was greater in higher concentration as compared to low concentration.

The root and shoot lengths are the most important parameters for salt stress because roots are in direct contact with soil and absorb water from soil and shoot supply it to the rest of the plant. For this reason, root and shoot length provides an important clue to the response of plants to salt stress ${ }^{[22]}$. Salt stress inhibited the seedling growth (root and shoot length, fresh root and shoot weight) but root length was more affected then shoots length. Inhibition of plant growth by salinity may be due to the inhibitory effect of ions. The reduction in root and shoot development may be due to toxic effects of the $\mathrm{NaCl}$ used as well as unbalanced nutrient uptake by the seedlings. It may be due to the ability of the root system to control entry of ions to the shoot is of crucial importance to plant survival in the presence of $\mathrm{NaCl}^{[23]}$. High salinity may inhibit root and shoot elongation due to slowing down the water uptake by the plant ${ }^{[24]}$ may be another reason for this decrease. Neumann indicated that salinity can rapidly inhibit root growth and hence capacity of water uptake and essential mineral nutrition from soil. Salt stress inhibited the growth of root more than shoot in Vigna radiata $(\mathrm{L})$. Demir and Arif ${ }^{[25]}$ also obtained similar results. They observed that the root growth of safflower was more adversely affected compared to shoot growth by salinity. Our results were also similar with the findings of Hussain and Rehman ${ }^{[26,27]}$. They found that the roots of seedlings were more sensitive than the shoots. It has been reported that the plants had the reduction in their fresh weights because of the proportional incerase in $\mathrm{Na}^{+}$concentration, which could imply that an ionic effect was being manifested. However, one could argue that because dry weights were not much affected compared to the fresh weights, growth reduction would be attributable to osmotic effects. Similar kind of result was observed by Jeannette et al. that faster rate of germinationallowed the emerging seedlings to accumulate more biomass relative to the control but conversely, total fresh weight of root and shoot of cultivated accessions was significantly reduced with increased salt stress. 
Beside the salinity or salt stress, light also influence the growth of mung bean. The mung beans' seeds which were placed on the medium without the source of sunlight (in the dark) has the germination velocity in greater as compared to the seeds were placed on the medium with less light and with the source of sunlight. The seeds which were treated in the non direct sunlight ranks the second place right after the seeds were treated in the dark place in case of growing fast speed. And seeds which were treated in the light place grew the slowest as compared to others. This is in line with the theory mentioned that the growth in plants was influenced by auxin (growth plant regulator). Auxin could not work (damaged) if it was affected by sunlight. Thereby seeds which are situated on the direct sunlight grow slowly, seeds which are situated on the dark place grew faster, meanwhile the seeds which are situated on the non direct sunlight will be luffed to the source of light. This happens due to the part of the plants which are not affected by sunlight will grow much faster than the ones which are affected by sunlight as well. In result, plant grows luffed to the source of sunlight comes into. Sunlight is very important for the process of photosynthesis to many plants but another effect of this sunlight is to suppress the growth of plant cell. Growth which is affected by sunlight will be shorter in length rather than those plants grew in the dark place. This event is called ethiolation. The dark condition also trigger the auxin production. Auxin is one of the plant growth regulators mostly found in meristematic cells, such as on the tip of root as well shoot tips. Therefore plants will be more rapid growing. Auxin production will be inhibited in the plants that is frequently in lights ${ }^{[28]}$.

\section{REFERENCES}

[1] Raven, P.H., R.F. Evert., S.E. Eichhorn. 2005. Biology of Plants, $7^{\text {th }}$ Edition. New York: W.H. Freeman and Company Publishers, pp. 504-508.

[2] Siegel, S.M., L.A. Rosen. Effects of Reduced Light Tension on Germination and Seedling Growth. Physiologia Plantarum, 15(3): 437-444.

[3] Neumann, P.M. 1995.Inhibition of Root Growth by Salinity Stress: Toxicity or an Adaptive Biophysical Response? In: Baluska, F., M. Ciamporova., O. Gasparikova, Eds., Structure and Function of Roots, Kluwer Academic Publishers, pp. 299-304.

[4] Yildirim, E., A. Dursun., I. Guvenc., A. Kumlay. 2002. The Effects of Different Salt, Biostimulant and Temperature Levels on Seed Germination of Some Vegetable Species. Acta Agrobotanica, 55(1): 75-80.

[5] Khajeh-Hosseini, M., A.A. Powell., I.J. Bingham. 2003.The Interaction Between Salinity Stress and Seed Vigour During Germination of Soybean Seeds. Seed Sciences Technology, 31(2): 715-725.

[6] Almansouri, M., J.M. Kinet., S. Lutts.2001. Effect of Salt and Osmotic Stresses on Germination in Durum Wheat (Triticum durum Desf.). Plant and Soil, 231(3): 243-254.

[7] Baldwin, A.H., K.L. McKee., I.A. Mendelssohn. 1996. The Influence of Vegetation, Salinity, and Inundation onSeed Banks of Oligohaline Coastal Marshes. American Journal Botany, 83(1): 470-479.

[8] Ungar, I. 1996.Effect of Salinity on Seed Germination, Growth, and Ion Accumulation of Atriplexpatula. American Journal of Botany, 83(2): 604-607.

[9] Hampson, C., G. Simpson. 1990. Effects of Temperature, Salt, and Osmotic Potential on Early Growth of Wheat Triticumaestivum. Canadian Journal of Botany, 68(2): 524-528.

[10] Shannon, M.C., C.M. Grieve. 1999. Tolerance of Vegetable Crops to Salinity. ScientiaHorticulturae, 78(1): 5-38.

[11] Bohnert, H.J., D.E. Nelson., R.G. Jensen. 1995. Adaptations to Environmental Stresses. The Plant Cell, 7(3): 1.099-1.111.

[12] Yuniati, R. 2004. Penapisan Galur Kedelai (Glycine maxL.) Toleran Terhadap Garamuntuk Penanaman di LahanSalin.Makara Sains, 8(1): 86-98.

[13] Simbolon, R., H.K. Emi., H. Yusuf. 2013. Evaluasi Toleransi TanamanKedelai (Glycine maxL.) Generasi M3 Hasil Radiasi Sinar Gamma Terhadap Salinitas, Jurnal Online Agroekoteknologi, 1(3): 1.186-1.207.

[14] Welbaum, G.E., T. Tissaoui., K.J. Bradford. 1990. Water Relations of Seed Development and Germinationin Musk Melon (Cucumismelo L.). III. Sensitivity ofGermination to Water Potential and Abscisic Acid During Development, Plant Physiology, 92(2): 1.029-1.037.

[15] Maas, E.V., R.H. Niemann. 1978. Physiology ofPlantTolerance to Salinity. In: Crop Tolerance andSuboptimal Land Conditions, pp. 277-299.

[16] [Ayaz, F.A., A. Kadioglu., R. Turgut.2000. Water Stress Effects on the Content of Low Molecular Weight Carbohydrates and Phenolic Acids in Ctenanthesetosa (Rose.) Eichler ,CanJ. Plant Sci.,80(3): 373-378.

[17] Hadas, A.1977. Water Uptake and Germination of Leguminous Seeds in Soils of Changing Matrix and OsmoticWater Potential, J. Exp. Bot., 28(2): 977-985. 
[18] Huang, J., R.E. Redmann. 1995. Salt Tolerance of Hordeum and Brassica Species During Germination and Early Seedling Growth, Can. J. Plant Sci. 75(3): 815-819.

[19] Mauromicale, G., P. Licandro.2002. Salinity and Temperature Effects on Germination, Emergence and Seedling Growth of Globe Artichoke, Agronomie. 22(1): 443-450.

[20] Gulzar, S., M.A. Khan., I.A. Ungar. 2001. Effect ofSalinity and Temperature on the Germination of Urochondrasetulosa (Trin.) C.E. Hubbard, Seed Sci. Technol., 29(1): 21-29.

[21] Jeannette, S., R. Craig., J.P. Lynch. 2002. SalinityTolerance of Vigna Species During Germination andEarly Seedling Growth, Crop Sci., 42(3): 1.584-1.594.

[22] Jamil, M., E.S. Rha. 2004. The Effect of Salinity $(\mathrm{NaCl})$ on the Germination and Seedling of Sugar Beet(Betavulgaris L.) and Cabbage (Brassica oleraceacapitata L.),Korean J. plant Res.,7(5): 226-232.

[23] Hajibagheri, M.A., A.R. Yeo., T.J. Flowers., J.C. Collins. 1989. Salinity Resistance in Zea mays Fluxes of Potassium, Sodium and Chloride, Cytoplasmic Concentrations and Microsomal Membrane Lipids, Plant, Cell and Environment, 12(3): 753-757.

[24] Werner, J.E., R.R. Finkelstein. 1995. ArabidopsisMutants with Reduced Response to $\mathrm{NaCl}$ and OsmoticStress, Physiol. Plant., 93(1): 659-666.

[25] Demir, M., I. Arif.2003. Effects of Different Soil SalinityLevels on Germination and Seedling Growth of Safflower (Carthamustinctorius L.), Turk. J. Agric., 27(1): 221-227.

[26] Hussain, M.K., O.U. Rehman. 1995. Breeding Sunflower for Salt Tolerance: Association of Shoot Growth and MaturePlantTraits for Salt Tolerance in Cultivated Sunflower (Helianthus annuusL.), Helia.,18(2): 6976.

[27] Hussain, M.K., O.U. Rehman. 1997. Evaluation of Sunflower (Helianthus annuusL.) Germplasm for SaltTolerance at the Shoot Stage. Helia.20 (2): 69-78.

[28] Harahap, F. 2012. Fisiologi Tumbuhan Suatu Pengantar. Medan: Unimed Press.

\section{AUTHORS' BIOGRAPHY}

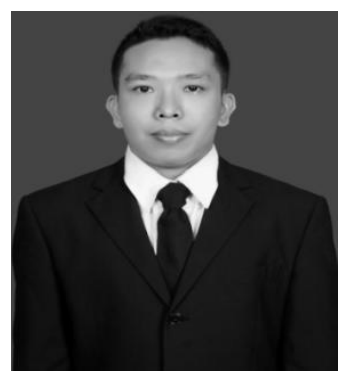

Muhammad Jamhari, was born in Desa Lalang, Tanjung Pura District, Langkat Regency, North Sumatera on June $1^{\text {st }}$, 1986from a father named Mr. H. Amran Darhany and a mother named Mrs. Hj. Siti Saedah. The author is the sixth son of seven siblings. The author has graduated from SDNegeri No. 057221 DesaLalang, MTs.Swasta Jam'iyah Mahmudiyah Tanjung Pura, and MAN 1 Tanjung Pura.

In 2004 the author continued his study in the Bachelor's Degree of Biology Education, Islamic University of North Sumatera (UISU) Medan and graduated in 2009 with the title of thesis "The Comparison of Students' Learning Outcomes Taught by Brainstorming and Recitation Learning Method on the Topic of Human Locomotor System at MAN 2 TanjungPura".

In 2015 the author subsequently pursued his study in the Postgraduate Program of Biology Education, State University of Medan (UNIMED) and graduated in 2018 with the title of thesis "The Effects of Visual Mapping and Science-Related Attitudes on Students' Critical Thinking and Problem Solving Skills at MAN 1 Tanjung Pura".

Citation: Muhammad Jamhari. "The Effects of Salinity and Light to the Seed Germination Ofmung Bean (Vigna Radiata L...)" International Journal of Humanities Social Sciences and Education (IJHSSE), vol 5, no. 7, 2018, pp. 19-25 doi: http://dx.doi.org/10.20431/2349-0381.0507004.

Copyright: (C) 2018 Authors. This is an open-access article distributed under the terms of the Creative Commons Attribution License, which permits unrestricted use, distribution, and reproduction in any medium, provided the original author and source are credited. 